\title{
The Spanish cod fishing industry: Radical production changes without significant changes in the innovation system
}

\section{Manuel González-López*}

\begin{abstract}
This paper studies the changes which have occurred in the Spanish cod fishing industry in the last few years. We also aim to understand the dynamics of industrial change and its relation to institutions, understood here as both formal and informal rules and conventions. Our results suggest that sometimes industries, in order to maintain their competitive position, need something more than incremental changes in their products or in the technologies that they use. As we can see with the Spanish cod fishing industry, major changes are needed which affect the institutional set-up of their production system. Nevertheless, even when major changes happen in the production sphere, this does not mean that major alterations happen in the way companies innovate, i.e. in their innovation system.
\end{abstract}

Key Words: institutions, innovation, innovation systems, cod fishing, change.

\section{Introduction ${ }^{[1][2]}$}

This paper studies the changes which have occurred in the Spanish cod fishing industry in the last few years. We also aim to understand the dynamics of industrial change and its relation to institutions, understood here as both formal and informal rules and conventions. Although innovation and change are usually understood to be key factors for economic success for both territories and industries, sometimes to innovate in a narrow sense is not enough. In some cases the survival of a given industry entails the alteration of existing institutions and major routines (David, 1993). Although some authors have already analyzed this issue (Granovetter, 1992; Grabher, 1992; Lindkvist \& Sanchez, 2008), more research is needed to understand in depth the relationship between innovation and institutions. Moreover, we also analyze the changes that occurred in the way how this industry organizes its innovation processes, i.e. the

Universidade de Santiago de Compostela, ICEDE Research Group - Department of Applied Economics, Campus Norte, 15782 Santiago de Compostela, Galicia - Spain, Manuel.gonzalez.lopez@usc.es.

1 This paper has been written thanks to the support given by the project "The Norwegian-Spanish salted fish project: The Spanish salted fish market and the opportunities for the Norwegians" (NFR/KMB prosject: 185126/110).

2 This paper has strongly benefited from the comments and suggestions made by Professor Knut Lindkvist, from the University of Bergen and Alta. We also thank Professor Marina Candi, from Reykjavik University, for her valuable comments. 
changes in its Innovation System (IS). We try to see whether changes at the production level have come together with changes at the IS level.

The paper proceeds as follows. In section two we discuss the relationship between innovation and institutions in order to achieve a better understanding of such a relationship. We also discuss the importance of the systematic and institutional perspective when understanding a firm's innovation process, based on the well-known innovation system approach. In section three we start by presenting the results of field research conducted in the Spanish cod fishing industry continuing with a description of the production changes that have occurred in this industry during recent years. In section four we try to see if the changes in the productive sphere have also been accompanied by changes in the industry's IS. Finally, some conclusions are included at the end of the paper that summarize our main results and considerations.

\section{Innovation, institutions and change}

As pointed out by different authors, during the last 25 years the disciplines of economic geography and regional development have experienced important progress (Martin, 1999; Scott, 2000). Part of this resurgence is due to the contribution of a number of schools and authors coming from different traditions. Among these contributions we could mention the Italian School that recovered the Marshallian concept of industrial districts (Becattini, 1987), the Californian School and the flexible specialization paradigm that emphasized the breakdown of Fordist production forms towards more flexible ones (Scott, 1988; Piore and Sabel, 1984) and the Gremi School based on the concept of "milieux innovateurs" (Aydalot, 1986; Crevoisier, 2004). According to Scott (2000) these contributions shared a general discontent with dominant neoclassical economics. Among other reasons, this is related to the fact that they usually pay attention to the development particularities of territories and sectors, instead of aiming at a general theory fitting all. Another common point was the understanding of the process of economic development as a systemic (interactive) process where the behavior of economic agents is shaped by institutions, rules and conventions. Therefore, each territory and industry will show a specific pattern of development marked by historical, technological, social and cultural factors.

\section{Institutions and innovation}

Institutions are closely related to the process of economic change. In this regard Edquist and Johnson $(1997,46)$ define institutions as: "sets of commons habits, routines, established practices, rules, or laws that regulate the relations and interactions between individuals and groups". Institutions, according to the referred authors, can be formal (such as laws and regulations) or informal (like conventions and habits). Taking the previous definition as a basis we could state that a contradictory relationship between institutions and innovation exists. Thus, institutions, both formal and informal, stimulate innovation because they reduce uncertainties, coordinate the use of knowledge, mediate conflicts, and provide incentives (Carlsson and Jacobson, 
1997). Nevertheless, to innovate also implies to alter existing routines, habits and even legal frameworks (Nelson and Winter, 1982; Granovetter, 1992; Hayter, 2004). The former applies particularly when dealing with radical innovations or important changes occurring in one industry. Douglas North (1994) has argued about the nature of economic change pointing out that whilst most of the time it is a matter of decisions based on existing routines and institutions, some changes might entail the alteration of such routines. These decisions: "involve altering existing 'contracts' between individual and organizations. Sometimes that re-contracting can be accomplished within the existing structure of property rights and political rules, but sometimes new contracting forms require an alteration in the rules. Equally, norms of behavior that guide exchanges will gradually be modified or wither away. In both instances, institutions are being altered" (North, 1994, p. 361). We could infer from North's words that although some innovations are made within the existing institutional framework, others imply the alteration of such a framework.

David (1993) has also referred to the previous issue indicating that sometimes, in order to survive, industries must change their entire institutional framework upon which they are situated. "Thus, institutional structures, being more rigid and less adept at passively adapting to the pressures of changing environments, create incentives for their members and directors to undertake to alter the external environment. Since there are many circumstances in which the external environment proves intractable, organizations and institutions are subject (in ways that properly designed technologies are not) to pressures and stresses that may cause them to abruptly collapse and dissolve or to be captured, dismembered and ingested by other competing organizations" (David, 1993, p. 218).

Similarly, Lindkvist \& Sánchez (2008) have also discussed the relationship between innovation and institutions, although referring to "conventions" (non-formal institutions). The authors referred particularly to natural resource-based industries and they point out that those industries that have been successful usually show an adaptive behavior of their conventions to new contexts. Nevertheless, other industries show less success precisely because of the rigidity of the existing conventions.

Ultimately we can conclude that there are situations where an industry needs to break the existing institutional arrangements (formed by rules, conventions, norms, etc.) in order to survive. This could mean an entire revolution on their production and IS or just partial changes affecting their components and some of their institutions. As we will try to show in this paper, there are reasons to think that the Spanish cod fishing industry has been involved during the last few years in a deep structural change. Such changes go further than simple innovations in products or processes and have implied important changes also from an institutional viewpoint.

\section{Innovation Systems and the innovative strategies of firms}

The systemic and institutional perspective shared by the new schools of Economic Geographers and Regional Economists is also found in contributions that focused their interest on the study of innovation and particularly in the so-called Innovation System 
(IS) approach. This approach focuses on the specificities shown by the innovative process at countries, regions and industries (Lundvall, 1992; Cooke et al., 1998; Howells, 1999; Malerba, 2002). The IS literature stands on two major theoretical frameworks. The first is the post-Schumpeterian perspective known as the evolutionary school (Nelson \& Winter, 1982; Dosi, 1982) which emphasizes, like Schumpeter did, the dynamic character of the economy in contrast with the neoclassical focus on equilibrium. Such a dynamic character would be explained by new combinations of the productive factors -innovations that are path-dependent, i.e. they are determined by previous changes in technologies and - in broad terms - in the economic structure. That would explain why each sector or territory follows different innovation trajectories shaping different IS. The other theoretical source of the IS approach is the so-called "interactive learning theories". These theories understand innovation as a ubiquitous phenomenon that is the product of multiple and continuous learning processes where multiple agents participate.

Although the innovation system approach was initially applied at the national level, it was later extended to the regional level (Cooke et al., 1998; Howells, 1998; etc), and also to the sectoral field. In this regard, Malerba (2002) defines a sectoral system of innovation and production as a set of products (new and existing ones) with specific uses as well as a set of agents that carry out market and non-market interactions aimed at creating, producing and selling those products. Thus sectoral systems own a base of knowledge, technologies, inputs and associated demands. Interactions occurring within the system are the origin of innovations and they are based on multiple channels like communication, exchange, cooperation or competition processes. Individual companies may benefit from knowledge sources in their environment by interacting with and learning from other firms, suppliers, customers, universities, knowledge organizations, and other government organizations (Lundvall 1992; Edquist 1997 , etc). Likewise an innovation system can itself be understood as an institution or a set of institutions because it refers to the specific way a sector organizes its innovative behavior, therefore made up of formal and informal arrangements among stakeholders.

The systemic nature of IS does not mean that individual behavior (agency) is not important. On the contrary, a major factor to understand the direction of changes at the industrial level concerns the strategies of firms when confronting market changes (Schamp, 2005). Therefore the decision making by firms related to their internal learning processes or to their responses to external changes will also explain alterations at the IS level. A large literature exists when dealing with different innovative strategies of firms both at an individual and aggregate level (Freeman, 1974, Pavitt, 1984, etc). As pointed out by Freeman (1974), in line with the Evolutionary Theory of firms, organizations differ in part due to their innovation strategies. The author suggested that whilst some companies follow traditional, dependent or imitative strategies and hardly get involved in R\&D activities (apart from adaptive R\&D), others present a more active behavior regarding innovation (defensive or offensive strategies). A relationship can be found 
between Freeman's classification and Pavitt's well-known taxonomy where, based on the analysis of firms' strategies, different sectoral patterns of innovation are identified (Pavitt, 1984). While some sectors, like primary activities or traditional industries, are characterized as "supplier dominated" from the technology viewpoint, others would be more prone to carry on their own innovative activities ("science based" sectors or "specialized suppliers" sectors). We could hence say that the response to technological change varies according to the type of firms and sectors.

The previous contributions, focused on the technological profile of firms and industries, have somehow been challenged by more recent perspectives on innovation. In this sense it is worthwhile to include here the differentiation made by authors like Jensen et al, (2007) between the STI (science-technology) mode of innovation and the DUI (doing, using and interacting) mode. Both modes refer to the channels used by firms (or sectors) to incorporate knowledge in such a way that the STI mode rests more on scientific (explicit) knowledge, while the DUI mode is rather related to implicit or tacit knowledge. The concept of knowledge transfer is substituted here by the concept of learning by doing, using, and interacting. Thus, while the STI is narrowly linked to formal processes such as carrying out R\&D activities, formal collaboration with universities and research centers and so on, the DUI mode of innovation rests more on informal contacts between users, producers and providers of products and technologies. Of course both modes might (and do) appear combined in the same sector and even in the same firm, nevertheless the status quo among both modes could be altered by a firm's or the entire sector's strategies when they react to changes in the competitive environment. One of these strategies (usually promoted by public policies), refers to the systematization of the innovation function in order to undertake changes in the production system. When such strategy is extended to the sector level then we could say that an important change in the Sectorial Innovation System is going on.

In this paper we will also try to see whether the changes that have happened in the Spanish cod fishing industry during the last years have been accompanied or not by changes in its system of innovation.

\section{Production changes in the Spanish cod fishing industry}

\section{Data collection}

In order to collect the information needed for our research, we designed a questionnaire that was used for the interviews carried out with the companies' managers. The industry is currently formed by five companies, although we finally obtained direct information from four companies since one refused to provide any information. Four interviews were carried out at the companies' headquarters, three interviews took place in San Sebastián (Basque country) and one in Vigo (Galicia). The interviews were carried out between the 23 November and 5 December 2009. In addition, we captured relevant opinions and views from the persons interviewed. On top of the interviews, during the 
processing of information and in order to clarify some aspects and validate the results, a number of phone calls were made to the companies. Finally, since the sector is very small and all companies know each other, we gained information not only related to each company but to the whole fleet and industry as well.

\section{The Spanish cod fishing industry: Presentation and historical review}

The Spanish cod fishing industry is currently composed of five companies that manage a fleet of nine trawlers actively dedicated to cod fishing. At the beginning of 2009, there were six companies but one decided to stop its activities and transfer their fishing rights to another Spanish company. Traditionally, the cod fishing industry was located in two regions: Galicia and the Basque Country. Nowadays, two companies locate their headquarters in Vigo (Galicia), while three are in San Sebastián (Basque Country). Nevertheless, only three vessels are based in San Sebastián (Pasaia port), while the other six have their base in the Port of Vigo.

Total revenues of this industry have varied between $€ 20$ and $€ 25 \mathrm{~m}$ in the last 10 years, where a clear trend (decreasing or increasing) is not observed. Average revenues by firm have varied between $€ 3.3$ and $€ 4.5 \mathrm{~m}$ during that period. Regarding employment, a much clearer declining trend is observed. Total employment has moved from 158 employees in 1998 to 79 employees in 2007. An increase in productivity (revenue by employee) has taken place in the period and this is most probably related to production changes and innovations.

Table 1. General information of the Spanish codfish trawler fleet firms

\begin{tabular}{|c|c|c|c|}
\hline Company & Location of headquarters & $\begin{array}{c}\text { Codfish } \\
\text { quote share }\end{array}$ & $\begin{array}{l}\text { Number of vessels } \\
\text { actively dedicated } \\
\text { to cod fishing }\end{array}$ \\
\hline Pesquera LaurakBat S.A. & $\begin{array}{l}\text { Pasaia - San Sebastián } \\
\text { (Basque Country) }\end{array}$ & $9.0 \%$ & 1 \\
\hline Velaspex S.L. & $\begin{array}{l}\text { Pasaia - San Sebastián } \\
\text { (Basque Country) }\end{array}$ & $14.8 \%$ & 2 \\
\hline $\begin{array}{l}\text { Pesquera Rodríguez S.A. } \\
\text { (Pescafria) }\end{array}$ & San Sebastián (Basque Country) & $27.4 \%$ & 2 \\
\hline $\begin{array}{l}\text { Pesquera Ancora S.L. } \\
\text { (FormerTranspesca S.A.). }\end{array}$ & Vigo (Galicia) & $24.1 \%$ & 2 \\
\hline Valiela S.A. & Vigo (Galicia) & $24.4 \%\left({ }^{*}\right)$ & 2 \\
\hline
\end{tabular}

The Spanish cod fishing industry has a long tradition and is narrowly linked with the Spanish long-distance fishing history. In 1924, a Galician trawler based in Vigo initiated its cod fishing activities in the waters of Newfoundland. Five years before, in 1919, the Basque company PYSBE (Pesquerías y Secaderos de Bacalao en España S.A. ${ }^{[3]}$ )

3 PYSBE: Cod fisheries and Dryers of Spain. 
had been established; nevertheless this company did not start its fishing activities until 1927. In 1929 fishing in Icelandic and Northern European waters took place for the first time. It must be pointed out that in the beginning the Spanish fleet used a single trawler system and the incorporation of the traditional "pair trawling" system did not take place until 1949 (Oya, 1974)[4].

On a global level, the Spanish fishing fleet became the third largest at the end of the 1960s with 15 single and 64 pair trawlers. Catches reached 300,000 tons at that time, basically from the Northwest Atlantic fisheries. As it is widely known, both changes in the International Law of the Sea and stock declines due to over-exploitation forced the reduction of captures (Zeller and Pauly, 2004). Since the establishment in 1977 of the Economic Exclusive Zones (EEZs) in the European Community (EC), Canada, United States and Norway, Spanish codfish quotes have progressively decreased; and at the end of that decade catches had declined to less than 30,000 Tn.

The entrance of Spain in the EC in 1986 marked another relevant point in the recent history of the cod fishing fleet. The EC established important limitations to cod fishing which in practice meant the closing of all community fishing grounds (Baltic Sea, North Sea, Kattegat and Skagerrak) to the Spanish fleet. Meanwhile, the NAFO fisheries suffered a strong crisis at the beginning of 1990s deriving from the ban of cod fishing in those fisheries (Hilborn and Walters, 1992). Since then, the Spanish fleet has developed its activity in the Norwegian EEZ (based on the agreements between this country and the EC) and at the Svalbard fishing ground. The Spanish quota reached around 12,000 tons in 2008 and it was distributed among six companies that, as we mentioned previously, became five at the end of $2009^{[5]}$.

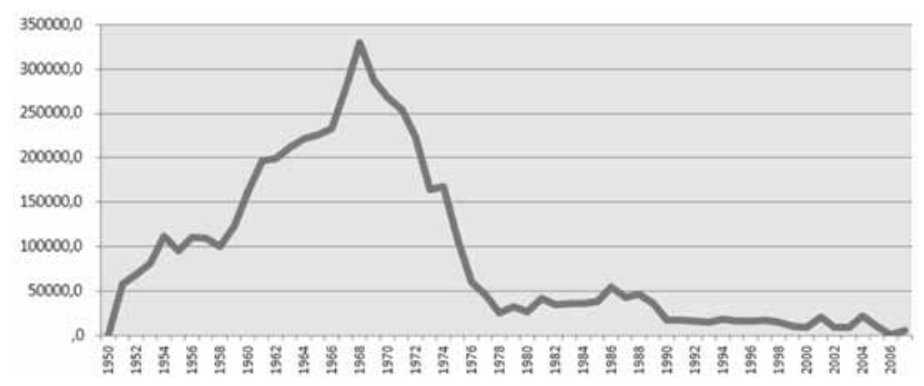

Figure 1. Volume of production, codfish, Spain (Tn). 1950-2006

Source: Own elaboration based on FAOSTAT. Global Production Statistics 1950-2007.

4 At the moment three companies use the traditional "pair trawling" system while the other two have recently changed to a single trawler system ("bou" in Spanish).

5 NAFO fisheries have recently re-opened although the quota given to the Spanish fleet is not large enough to initiate a fishing campaign there. 


\section{Codfish production: Traditional systems and recent changes}

The traditional method of codfish production of the Spanish trawler fleet was to salt it on-board. This method for salting cod is also known as dry salting or kench curing where solid salt is rubbed into the fish meat, the fish is then pile-stacked in the trawler with alternate layers of fish and salt. The pile salting method results in the dehydration of much of the salted fish because of the increasing pressure from the overburden on the fish in the lowest part of the batch. The salted fish was then landed in the Basque or Galician ports and usually dried again at inner Spanish regions with an appropriate dry climate ${ }^{[6]}$. Lindkvist et al, (2008) have suggested that this method arose to optimize the vessels' stock capacity since the space on board schooners is limited. This aspect is indeed crucial when dealing with long-distance fishing, as is the case of the Spanish cod fishing fleet.

The technological process described above could be considered a part of a whole production system that also encompassed specific market relationships and conventions. For instance, there were specific commercializing channels for the Spanish fleet to use to sell their "bacalao verde"(traditional denomination of the codfish processed by Spanish trawlers) to Spanish dealers or industrial processers that were in charge of distributing the product to retailers (supermarkets, restaurants, etc). The links between the companies and their clients were in most cases based on long term and well-established relationships founded on mutual trust. In many cases the fishing companies receive purchase commitments in advance (i.e. for fish yet to be caught). Moreover, this particular product achieved a dominant position in the Spanish market during the boom of the Spanish cod fishing industry. It showed a particular appearance (split or butterfly shaped) color (yellow-green) and taste. It also required a specific procedure prior to being cooked consisting of desalting and dehydrating the salted fish over a couple of days. As pointed out by Lindkvist et al, (2008) these conventions and rules were also followed by foreign producers who exported salted fish to the Spanish market.

The traditional process of on-board salting is still in use, although it is being progressively abandoned and substituted with a freezing system. At the moment three companies still maintain the traditional system even though all three combine it with the new one. All in all, in 2009 around $68 \%$ of the catches were frozen and only $32 \%$ used the traditional on-board salting system. The substituting of the traditional method by the freezing one does not mean that the cod is sold to the final customer as frozen fish since a relevant part of the frozen fish is eventually salted by the processers. This happens particularly with catches landed in Norway (at least two out of five companies land part of their catches in Norway).

6 The landing of on-board salted fish currently takes place only at one Spanish port situated near to Vigo (Cangas) because this is the only port where the needed infrastructure and labor for salt fish unloading is available. The salted fish is usually bought by intermediaries who use Vigo (Cangas) as a temporary stock point before sending it to driers situated in other parts of Spain. 
Changes in the conservation system were accompanied by other changes related to product characteristics. The Spanish companies of cod fishing currently sell three basic types of products that combine two conservation systems, frozen and salted:

- Split cod or "Butterfly". This is sold as the traditional salted fish but in some cases is also landed as frozen cod.

- HG (headed and gutted). This is sold mainly as frozen (but part of it is later salted by processers).

- $\quad$ Fillets. These are sold by the fishing firms mainly as frozen.

Apart from the previous basic products at least one company has launched other product innovations and is trying to sell little cod loins, "kokotxas" (cod cheeks), etc. Besides, most of the companies have implemented small changes in fillets affecting its appearance (and other aspects) in order to attend to market requirements.

Both product and process innovations have required the incorporation of new technologies. Thus in recent decades, one company has built a new trawler and another has undertaken deep transformation in their fleet. In both cases important changes were made in the processing plants. Innovations here regard the design of more efficient plants, the incorporation of new industrial cold systems, new conservation systems or new packing systems. Related to the previous point we must call attention here to an important issue. Thus, when we asked the company managers about the technologies used in their production process the interviewees indicated that in most cases they have been in use in the fishing sector for a long time. It is just in the last decade that the Spanish fleet has incorporated this already available technology. This means that innovation in the industry did not find technology barriers and therefore the main force for innovation is, very likely, "the market pull" (instead of the "technology push"). (Coombs et al, 1987).

Joseph Schumpeter (1942) used to include the opening of new markets among types of innovation. Relevant changes have occurred in recent years in the Spanish codfish industry also in this field. To some extent the traditional method of commercializing and the associated rules and conventions are still in use. Nevertheless, as in the production sphere, important changes have occurred in recent years.

Firstly, an internationalization process of sales has been taking place. At least two companies are now selling to clients situated in countries other than Spain and one of them (the largest in the industry) sells the majority of its catch abroad. Ultimately, and according to the information obtained from the companies, in 2009 around 59\% of total sales took place in the Spanish market, while $41 \%$ took place at international markets. An important part of foreign clients are located in Norwegian ports. The cod landed in Norway is usually a frozen cod product that is later salted (and probably a good part of it exported to Spain).

Secondly, some companies have tried to move to other clients apart from dealers and processers. We refer basically to retail chains located not only in Spain but also in countries like the United Kingdom or France. The products sold in these markets are 
usually fillets (particularly the UK where they are commercialized under the famous dish of "fish and chips").

Generally speaking we can affirm that the launch of new products by the Spanish cod fishing industry has been associated with changes in the market sphere. Thus whilst the traditional "bacalao verde" is sold exclusively to Spanish dealers or industrial processers, the new products are sold mainly to foreign clients, some of them retail branches. Thus the whole production system of the Spanish cod fishing industry seems to have been altered.

\section{Why is the Spanish cod fishing industry changing?}

We have seen that the Spanish cod fishing industry is introducing deep changes in its production and commercializing system. The result is the progressive abandoning of the traditional on-board salted fish, the production system that has characterized this industry since the beginning of the last century. The reasons have to do with a strong restructuring occurring in the Spanish salted fish market over recent decades, a process that has been described in depth by Lindkvist et al, (2008). Next we point some factors related to that restructuring:

- Social and cultural changes occurring in modern societies have led to a general trend of introducing frozen products into consumer diets. The incorporation of women to the labor market has reduced the time for typical home tasks like daily shopping or cooking in such a way that has made frozen products become very popular. Thus, codfish is increasingly consumed by final consumers as a frozen product, with presentations and tastes that may differ from the traditional salted one. In Figure 2 we can observe how frozen codfish is increasing its relative weight in the Spanish market while salted codfish (included in the category of fresh codfish) has reduced its quota ${ }^{[7]}$.

- Moreover, in the market segment of salted fish (still predominant in countries like Spain and Portugal), traditional on-board salted fish as a product shows some comparative disadvantages. According to the views of Spanish producers this is largely due to the eruption of foreign producers in the Spanish market since the 1980s. This opinion fits reasonably well with the results of the study made by Lindkvist et al, (2008), who highlighted the influence of Icelandic producers' strategies on the dynamics of the Spanish salted fish market. As a result, salted fish produced by a means of alternative salting methods is now dominant in the Spanish market. We refer to methods like direct brining that is more flexible in terms of production time and makes the desalting and dehydrating process unnecessary for consumers (since it is done by the producers). Moreover, a wide variety of salted fish products, like light salted fillets, have been introduced in the market. These products have better

7 We are aware that part of frozen codfish has previously been subject to a salting process, as is the case of the light salted frozen fillets. In any case it seems clear that frozen codfish is increasingly present in the Spanish market regardless of whether it has been salted or not. 
acceptance by consumers largely because of their appearance. On-board salting usually gives codfish a yellow appearance that does not attract consumers who associate freshness and quality with a white color. Meanwhile, other methods can salt fish by maintaining the white appearance. Although the Spanish producers insist on the higher quality of their product and maintain that the traditional salted fish does not show cost disadvantages, they are aware of the market changes. One of the interviewees agreed by pointing out that: "it is too late to launch any strategy to maintain the traditional salted fish" ${ }^{[8]}$

- Finally, social, cultural and economic changes have also altered the traditional distribution channels of the Spanish codfish. Large supermarket and retail chains have become the key stakeholder in the Spanish food market, displacing, in the case of salted fish, the traditional dealers and processers that were dominant in the market. According to Lindkvist et al, (2008), this process has also been influenced by the Icelandic producers' strategies that established their own sales network, avoiding the traditional Spanish one: "They (the Icelandic producers) have been able to change Spanish production institutions and distribution systems. With their light salted frozen fillets, they have established innovative and new products that have required a new distribution system and that meet the demands of modern customers in the markets". (Lindkvist et al, 2008, p. 119).

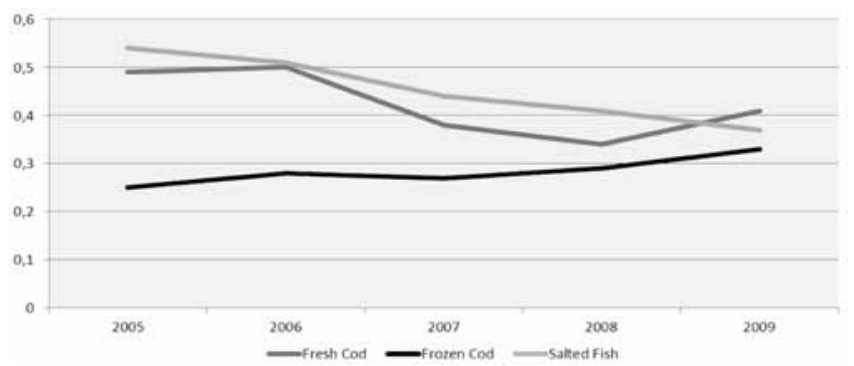

Figure 2. Codfish consumption per capita (Kg/population)

Source: Own elaboration based on the Base de datos de consumo en hogares of Ministerio de Medio Ambiente y Medio Rural y Marino.

\section{Changes in the IS of the Spanish cod fishing industry}

We have seen how the Spanish cod fishing industry has innovated in different fields but we still do not know if these innovations have been accompanied by changes in the way the industry incorporates knowledge. For this reason we asked the companies about the channels of knowledge incorporation and innovation. By this means we aimed to obtain a simplified picture of the Spanish cod fishing IS.

8 In this regard, during recent years a new product has entered the Spanish market. We refer to light salted fillets mostly coming from China and other Asian countries. They are produced based on frozen HG exported from Europe that is then filleted and exposed to a process of salt solution injection. According to the opinions of the interviewees the quality of this product is quite poor and its success lies both in its low prices and the lack of adequate labeling. 
The results indicate that the companies are rarely involved in explicit innovation activities. Thus, none of the companies undertake internal research and development (R\&D) activities, neither do they have specific departments or personnel involved in innovation. The lack of involvement also means an absence of collaboration for innovation with other companies, universities or other institutions. Furthermore, channels for innovation are in general not explicit or formal and show a rather passive innovative role of companies. Thus, all companies use contacts with clients, providers and personnel of other firms to incorporate knowledge. Although the questionnaire did not distinguish between formal and informal contacts, the persons interviewed pointed out that the informal contacts are used most often. All companies use internal learning processes as an innovation channel as well as the attendance of sector fairs or conferences and specialized publications. Finally, the acquisition of machinery is also used by all firms. Other means used, in this case not by all companies, refer to the hiring of specialized personnel or to training activities. The personnel in charge of technological or innovation issues are also employed as a channel for knowledge incorporation although we must indicate here that no company has specific personnel for these tasks but persons who are dedicated just occasionally to this field.

Regarding the importance given to each of the channels used to innovate or incorporate knowledge, the results reinforce the previous ones. Thus, formal and informal contacts together with internal learning processes and the acquisition of machinery and equipment are considered to be the most important channels to innovate. The rest of the channels demonstrate a medium importance, while specialized publications are considered to be of little importance.

Therefore, we are dealing here with an industry that is poorly involved in explicit innovative activities like R\&D or formal collaborations for innovation. For this reason, to optimize fishing and processing tasks firms incorporate technology embedded in machinery and equipment bought from world leading manufacturers. This confirms Pavitt's taxonomy where fishing sector was typified a "supplier dominated" sector from the technological viewpoint. Nevertheless the Spanish codfish companies have important advantages that draw on implicit knowledge, most of it coming from informal contacts and internal processes. These advantages draw on the accumulated "know-how" related for instance to the Galician and Basque rich tradition of the distant water fishing fleet. In this regard, even when dealing with the incorporation of new machines and equipment, it is very important to count nearby on world leaders' shipyards. Another advantage regards the established linkages with the Spanish market where "knowing who" (knows the market) and "knowing what" (the market wants) becomes very important. Finally, internal learning processes are also very relevant and, according to some opinions, they draw highly on the role of the captain and the technical inspector who own precise information about all processes happening on-board. All in all, the Spanish cod fishing industry seems to be following the DUI mode for knowledge incorporation and innovation and almost nothing new, as stated by the persons interviewed, has been done in this regard. We could maybe point to a somehow significant change referred to the taking over of a new generation of 
firms' managers (in most cases the children and grandchildren of the company founders) who is most cases are at higher educational levels than their predecessors.

We can conclude that no important changes have happened in the way the companies incorporate knowledge and finally innovate. While other companies and industries, in order to change their production system, have been forced to undertake an explicit innovative effort and therefore to change the way they articulate their system of innovation, this does not seem to be the case in the Spanish cod fishing industry. On the contrary: the companies rely upon factors that have been "always there" like providers, internal knowledge and so on. For this reason we can affirm that no relevant changes have happened in the IS of this industry. ${ }^{[9]}$

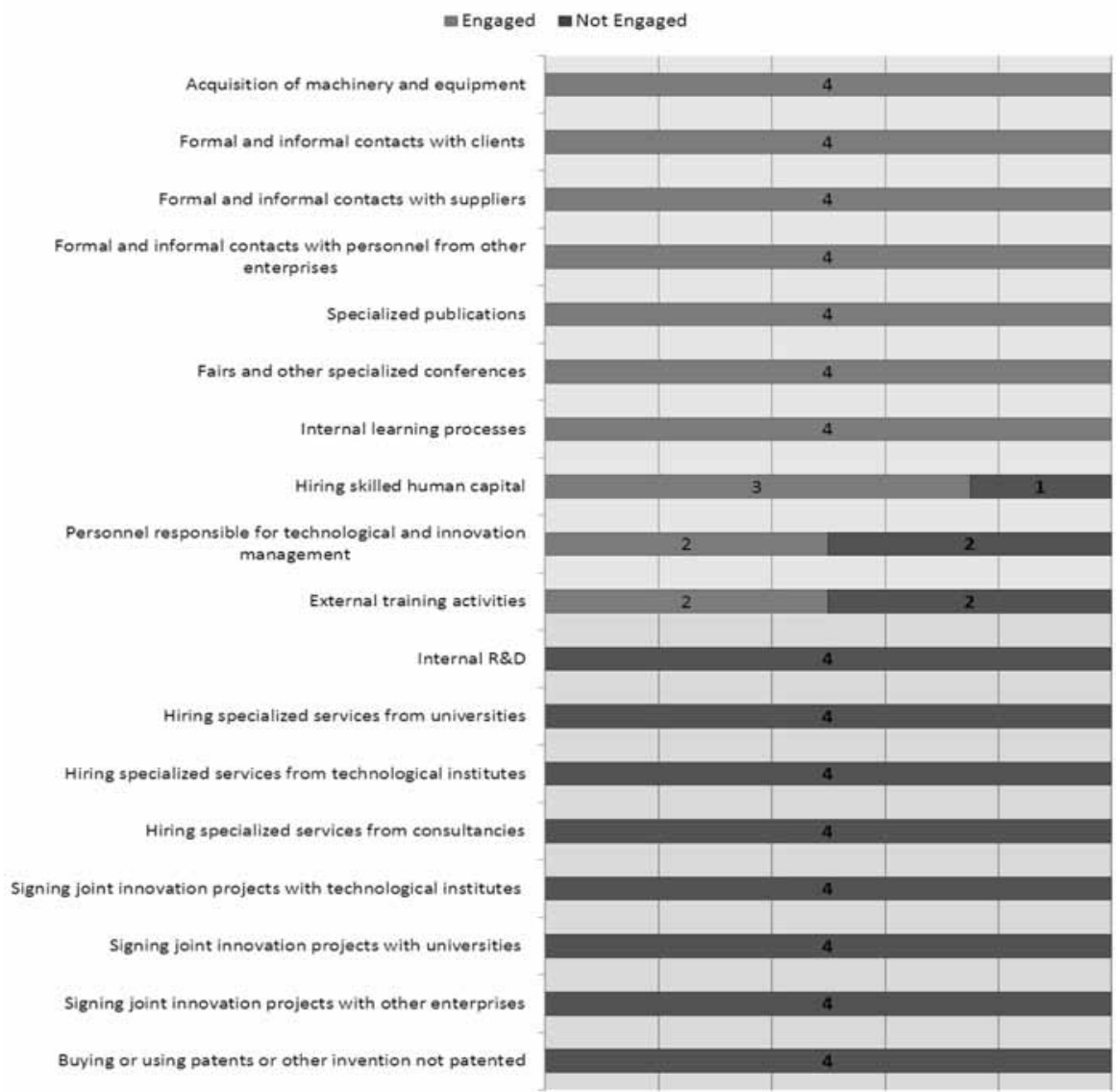

Figure 3. Use of channels for innovation and introduction of new knowledge into the company

9 The fact that the companies do not seem to have changed their innovation channels does not mean that no changes have happened at this level, it only means that the way the industry organizes its innovation activity has not suffered particular changes. Nevertheless it is obvious that the "accumulated" internal knowledge has continued to "accumulate" or that machinery providers do not supply as before. 


\section{Conclusions}

In this paper we have analyzed the changes that have occurred in the Spanish cod fishing industry in recent years. In order to understand such changes we conducted field research to investigate the recent innovative patterns of this industry. Innovations are understood here from a systemic viewpoint, i.e. as the response of a particular industry not only to changes in technologies but also to social or cultural factors. Our results indicate that innovations implemented by the Spanish cod fishing industry go further than simple incremental innovations in products or processes but are accompanied by a deep institutional change. The main driver of such deep changes is the restructuring which has happened in the Spanish salted fish market, the traditional market of the Spanish cod fishing industry. As mentioned, social and cultural changes occurring in Spain during recent decades together with the eruption of the strategies followed by strong foreign competitors have changed the rules of the game in the market.

As a result of the restructuring of the Spanish salted fish market, the tiny Spanish cod fishing industry has been obliged to restructure itself in order to survive. This has been done by different means: a) incorporating the freezing conservation system and progressively abandoning the on-board salting system (process innovation); b) diversifying its product offer by incorporating new products like salted/frozen fillets and others (product innovation); and c) diversifying their market strategies by both internationalizing their sales and selling directly to retailer and supermarket chains.

Nevertheless, in this case changes in the production system do not seem to have been accompanied by significant changes in the IS. The way and channels through which the Spanish cod fishing companies innovate and incorporate knowledge have not changed recently. In order to innovate, the companies basically rely on machinery purchases, internal know-how and informal contacts with clients, providers and other firms of similar industries. The sector fits therefore quite well with the Pavitt (1984) category of "supplier dominated" sector from the technological viewpoint and, from a broader perspective on innovation, it is closer to the DUI than to the STI mode of knowledge incorporation.

Therefore we can conclude that sometimes industries, in order to maintain their competitive position, need something else than incremental changes in their products or in the technologies that they use. Like the Spanish cod fishing industry, major changes are needed which affect the institutional set-up of their production system. Nevertheless, even when major changes happen in the production sphere this does not mean that relevant alterations happen in the way companies innovate, i.e. in their IS. 


\section{References}

Aydalot, P. (1986). Milieux innovateurs en Europe. Paris: GREMI.

Becattini, G. (1987). Mercato e forze locali: il distretto industrial. Bologna: II Mulino.

Bureau van Dijk Company (2010). SABI: Iberian Balance-sheets Analysis System. Bureau

Van Dijk Company: Brussels, Belgium.

Carlsson, B. \& Jacobsson, S. (1997). Diversity creation and technological systems:

a technology policy perspective. In Edquist, C. (1997). Systems of innovation: technologies, institutions, and organizations. London: Pinter, 266-294.

CETMAR\&OPTI (2005); El futuro de la tecnología de la pesca. Centro Tecnolóxico do Mar e Fundación OPTI. Vigo.

Cooke, P., Heidenreich, M. and Braczyk, H. (1998). Regional innovation systems: The role of governances in a globalization world. London: UCL Press.

Coombs, R; Saviotti, P. Walsh, V. (1987). Economics and Technological Change. Rowman \& Littlefield.

Crevoisier, O. (2004). The Innovative Milieus Approach: Toward a Territorialized Understanding of the Economy? Economic Geography, 80 (4), 367-379.

David, P. A. (1993). Why are institutions the 'Carriers of History'?: Path dependence and the evolution of conventions, organizations and institutions. Structural Change and Economic Dynamics, 5(2), 205-220.

Doloreux, D. (2002). What we should know about regional systems of innovation? Technology in Society, 24, 243-263.

Dosi, G. (1982). Technological paradigms and technological trajectories. Research Policy, 11, 147-162.

Edquist, C. (1997). Systems of innovation. Technologies, Institutions and Organizations. Oxon: Pinter.

Edquist, C., Johnson, B. (1997). Institutions and organizations in systems of innovation. In Edquist, C. (1997). Systems of innovation. Technologies, Institutions and Organizations. Oxon: Pinter, 41-63.

Edquist, C. (2001). The system of innovation approach and innovation policy: an account of the art of the state of the art. Paper presented at the DRUID Conference, Aalborg, June 12-15, 2001.

Edquist, C. (ed.). (1997). Systems of innovations. London: Pinter.

FAO (2009). Fish and fishery products: World apparent consumption statistics. FAO Yearbook / annuaire / anuario 2008. Rome, FAO, 2009.

Freeman, C. (1974). The economics of industrial innovation. London: Frances Pinter. FAOSTAT (2009). Global Production Statistics 1950-2007. http://faostat.fao.org. Rome, FAO.

González, M. (2010). The institutions-innovation dilemma: the case of coastal fisheries. Working Paper of the Department of Applied Economics (to be published).

Grabher, G. (1992). The weakness of strong ties. The lock-in of regional development in the Rurh area. The embedded firm. On the socioeconomics of industrial networks. New York: Routledge. 
Granovetter, M. (1992). The impact of social structure on Economic outcomes. Journal of Economic Outcomes, 19(1), 35-50.

Hayter, R. (2004). Economic geography as dissenting institutionalism: the embeddedness, evolution and differentiation of regions. Geografiska Annaler, 86 (B), 95-115.

Hilborn, R., Walters, C. (1992). Quantitative fisheries stock assessment: Choice, dynamics and uncertainty. New York: Chapman and Hall.

Howells, J. (1999). Regional systems of innovation? In Archibugi, D., Howells, AND Michie, J. (1999). Innovation policy in a global economy. Cambridge University Press, 67-93.

Jensen, M.B., Johnson, B., Lorenz, E., Lundvall, B.A. (2007). Forms of knowledge and modes of innovation. Research Policy, 36 (5), 680-693.

Lindkvist, K. B., Gallart-Jornet, L., Stabell, M.C. (2008). The restructuring of the Spanish salted fish market. The Canadian Geographer / Le Géographe Canadien, 52(1), 105120.

Lindvist, K.B., Sanchez, J.L. (2008). Conventions and innovation: A comparison of two localized natural resource-based industries. Regional Studies, 42(3), 343-354.

Lundvall, B.-Å. (1988). Innovation as an interactive process: from user-producer interaction to the national system of innovation. In Dosi, G., Freeman, C., Nelson, R., Silverberg, G., Soete, L. (eds.). Technical change and economic theory. London: Pinter, 349.369.

Lundvall, B.-Å. (ed.). (1992). National system of innovation: Towards a theory of innovation and interactive learning. London: Pinter.

Malerba, F. (2002);. Sectoral systems of innovation and production. Research Policy, 31(2), 247-264.

Martin, R. (1999). The new 'Geographical Turn' in economics: Some critical reflections. Cambridge Journal of Economics, 23, 63-91.

Ministerio de Medio Ambiente y Medio Marino (2009). Bases de datos de consumo de hogares. Available at http://www.mapa.es/es/alimentacion/pags/consumo/BD/ consulta.asp

Nelson, R. R. (ed.). (1993). National innovation systems: A comparative analysis. New York: Oxford University Press.

Nelson, R. R., Winter, S. G. (1982). An evolutionary theory of economic change. Cambridge: Harvard University Press.

North, D. (1994). Economic performance through time. American Economic Review, 84(3), 359-368.

Oya, J. (1974). Las pesquerías españolas en onda larga: la "gran pesca" del bacalao en los bancos del Atlántico noroccidental. Revista de Geografía, 10, 48-78.

Pavitt, K. (1984). Sectoral patterns of technical change: towards a taxonomy and a theory. Research Policy, 13 (6), 343-373.

Piore, M.J., Sabel. C.F. (1984). The second industrial divide: Possibilities for prosperity. New York: Basic Books. 
Schamp, E.W. (2005). Decline of the district, renewal of firms: an evolutionary approach to footwear production in the Primasens area, Germany. Environment and Planning A., 37, 617-634.

Schumpeter, J. A. (1942). Capitalism, socialism and democracy. New York: Harper $\&$ Brothers.

Scott, A.J. (1988). New industrial spaces: flexible production organization and regional development in North America and Western Europe. London: Pion.

Scott, A.J. (2000). Economic geography: the great half century. Cambridge Journal of Economics, 24, 483-504.

Zeller, D., Pauly, D. (2004). The future of fisheries: from 'exclusive' resource policy to 'inclusive' public policy : Perspectives on eco-system-based approaches to the management of marine resources. Marine Ecology. Progress series, 274, 295-303.

\begin{abstract}
Polish)
Niniejsza praca analizuje zmiany w hiszpańskim przemyśle połowu dorsza w okresie kilku ostatnich lat. Autorzy próbujq również zrozumieć dynamikę zmian przemysłowych oraz jej zwiqzzek z instytucjami, rozumianymi tutaj jako formalne i nieformalne reguły i konwencje. Wyniki naszych badań sugerujq, że czasami aby utrzymać konkurencyjność, branże potrzebujq czegoś więcej niż tylko stopniowych zmian produktów czy technologii. Jak widać na przykładzie hiszpańskiej branży połowu dorsza, potrzebne sq gruntowne zmiany, które wpłynq na cały system produkcji. Nawet jeżeli sferę produkcyjnq dotknq gruntowne zmiany, nie oznacza to poważnych zmian w sposobie dokonywania innowacji przez firmy, czyli w w ich systemie innowacji.

Słowa kluczowe: instytucje, systemy innowacji, przemysł połowu dorsza, zmiana.
\end{abstract}

